\title{
PENGOLAHAN BANK SAMPAH SEBAGAI SUMBER DAYA MASYARAKAT DI DESA KALIKATIR KECAMATAN GONDANG
}

\author{
Yunia Dwie Nurcahyanie $^{1)}$, Rusdiyantoro ${ }^{2)}$, Titik Koesdijati ${ }^{3)}$, Gempur Santoso ${ }^{4)}$, Djoko Adi Walujo ${ }^{5)}$ \\ 1,2,3,4,5 Fakultas Teknologi Industri, Universitas PGRI Adi Buana Surabaya \\ Email: '1yuniadwie@unipasby.ac.id, ${ }^{2}$ rusdi2008@gmail.com
}

\begin{abstract}
Abstrak
Pengabdian ini bertujuan untuk: 1) Implementasi pengolahan limbah; 2) Faktor-faktor yang mempengaruhi pemrosesan bank sampah; 3) Dampak pengolahan bank sampah di Desa Kalikatir Gondang Mojokerjo. Pengabdian ini menggunakan deskriptif kualitatif dengan lokasi penelitian di sebuah bank sampah di aula desa Kalikatir, Gondang, Mojokerto. Subjek penelitian ini adalah seorang warga desa yang mengumpulkan beberapa sampah rumah mereka yang dikumpulkan untuk menghamburkan anggota bank desa Kalikatir. Informasi tersebut diperoleh oleh manajemen bank sampah dan kepala desa sebagai penasihat bank sampah. Pengumpulan data menggunakan metode wawancara, observasi, dan dokumentasi. Kesimpulan dari semua hasil pengabdian menunjukkan bahwa: 1) pelaksanaan pengolahan bank sampah sebagai komunitas sumber daya di desa Kalikatir memiliki kegiatan yang meliputi sosialisasi bank sampah, pengumpulan sampah, pemilahan sampah, pelatihan keterampilan untuk bahan daur ulang dan evaluasi yang dilakukan sekali satu minggu; 2) Faktor-faktor yang mempengaruhi pengolahan bank sampah sebagai fasilitas untuk pengolahan limbah yang tidak memadai dan distribusi kinerja yang kurang spesifik; 3) Dampak pemberdayaan masyarakat melalui pengolahan bank sampah di Desa Kalikatir mampu memberikan penghasilan tambahan bagi anggota aktif. Membudayakan masyarakat pilah pilih sampah.
\end{abstract}

Kata kunci: bank sampah, pengolahan, pemberdayaan masyarakat

\begin{abstract}
This service aims to: 1) Implementation of waste processing ; 2) Factors that influence the processing of waste banks ; 3) Impact of waste banks processing in Kalikatir Gondang Mojokerjo Village. This service use a descriptive qualitative with a research location in a waste bank in the Kalikatir, Gondang, Mojokerto hall village. The subject of this service was a villager who collected some rubbish of their house that collected to waste bank members of Kalikatir village. The information was obtained by the waste bank management and head village as advisor of the waste bank. Data collection was use an interview, observation, and documentation methods. Conclusions of all serviceresults show that: 1) the implementation of waste bank processing as a resource community in the village of Kalikatir have activities that include socialization of waste banks, waste collection, waste sorting, skills training for recycled materials and evaluations that do once a week; 2) Factors that influence of waste banks processing as the facilities for waste processing that are inadequate and the distribution of performance that was less specific; 3) The impact of
\end{abstract}


community empowerment through the processing of waste banks in the kalikatir village on environmental aspects was given good impact as more clean the environment, economic aspects enough to provide the additional income for active members and more familiarize the community.

Keywords: community empowerment, processing, waste bank

\section{PENDAHULUAN}

Pada dasarnya bank sampah merupakan konsep pengumpulan sampah kering dan dipilah serta memiliki manajemen layaknya perbankan, Menurut Suryani (2016) pengelolahan sampah adalah sebuah kegiatan yang dilakukan dengan cara pengumpulan, pengangkutan, dan pemerosesan pendaur-ulangan atau pembuangan dari material-material sampah. Dalam melakukan pemberdayaan masyarakat bertujuan untuk memampukan masyarakat dengan setiap perlatihan-perlatihan yang akan diberikan oleh bank sampah untuk menambah nilai dengan mengumpulkan sampah kering yang akan ditukar dengan nilai rupiah. Kegiatan ini akan menambah pengasilan rumahan. Pada desa Kalikatir, Kec. Gondang, Kab. Mojokerto. melakukan kegiatan bank sampah. Masyarakat mengumpulkan sampah rumah tangga dan dikumpulkan di balai desa Kalikatir. Tetapi yang ditabung bukan uang melainkan sampah.

Warga yang menabung (menyerahkan sampah) juga disebut nasabah dan memiliki buku tabungan serta dapat meminjam uang yang nantinya dikembalikan dengan sampah seharga uang yang dipinjam. Sampah yang ditabung akan ditimbang dan dihargai dengan sejumlah uang, kemudian akan dijual di pabrik yang sudah bekerja sama dengan bank sampah. Sementara plastik kemasan dapat dibeli oleh pengurus PKK setempat untuk didaur ulang menjadi barang-barang kerajinan. Pendekatan yang sesuai dengan konteks masyarakat dan kesesuaian kebutuhan masyarakat menjadi kunci dari perubahan. Sementara pengembangan bank sampah ini juga akan membantu pemerintah lokal dalam pemberdayaan masyarakat untuk mengelola sampah berbasis komunitas secara bijak dan dapat mengurangi sampah yang diangkut ke Tempat Pembuangan Akhir (TPA. Inovasi pengolahan sampah dengan program bank sampah dapat meningkatkan pendapatan masyarakat setempat karena dari bank sampah ini bisa di pilah dan digunakan daur ulang

Fungsi dari Bank Sampah yaitu merupakan tempat menabung sampah yang telah terpilah menurut jenis sampah, sampah yang ditabung pada bank sampah adalah sampah yang mempunyai nilai ekonomis. Cara kerja bank sampah pada umumnya hampir sama dengan bank lainnya, ada nasabah, pencatatan pembukuan dan manajemen pengelolaannya, apabila dalam bank yang biasa kita kenal yang disetorkan nasabah adalah uang. Akan tetapi, dalam bank sampah yang disetorkan adalah sampah yang mempunyai nilai ekonomis, sedangkan pengelola bank sampah harus orang yang kreatif dan inovatif serta memiliki jiwa kewirausahaan agar dapat meningkatkan pendapatan masyarakat (Barat et al., 2018).

Daur ulang mempunyai pengertian sebagai proses menjadikan bahan bekas atau sampah menjadi bahan baru yang dapat digunakan kembali. Dengan proses daur ulang, sampah dapat menjadi sesuatu yang 
berguna sehingga bermanfaat untuk mengurangi penggunaan bahan baku yang baru. Dengan manfaat yang diperoleh adalah untuk menghemat energi, mengurangi polusi, dan mengurangi kerusakan lahan. Masalah lingkungan yang sangat kompleks termasuk masalah persampahan di daerah pedesaan atau di perkotaan (Rappocini and Jastam, 2012).

Pentingnya perancangan produk yang dilakukan tidak hanya dari industri ke konsumen, namun konsumen juga harus bertanggung jawab pada sampah yang dihasilkan (Series and Science, 2020)

Faktor-faktor yang mempengaruhi pengelolahan sampah diantaranya:

1. Sosial politik, yang menyangkt kepedulian dan komitmen pemerinah dalam menentukan anggaran APBD untuk pengelolaan lingkungan (sampah), membuat keputusan publik dalam pengelolaan sampah serta upaya pendidikan, penyeluhan dan latian keterampilan untuk meningkatkan kesadaran dan partisispasi masyarakat dalam pengelolaan sampah

2. Sosial demografi, yang meliputi sosial ekonomi (kegiatan pariwisata), pasar dan pertokoan, dan kegiatan rumah tangga).

3. Sosial budaya yang menyangkut keberadaan dan interaksi antar lembaga desa/adat, aturan adat (awig-awig).

4. kegiatan ritual (upacara adat/keagamaan), niai struktur ruang tri mandala, jiwa pengabdian sosial yang tulus, sikap mental dan perilaku warga yang apatis.

5. Keberadaan lahan untuk tempat penampungan sampah.

6. Keberadaan antar lembaga yang terkait dalam penggulangan masalah lingkungan (sampah).

Tujuan utama pendirian bank sampah adalah
1. Untuk membantu menangani pengolahan sampah diindonesia

2. Untuk menyadarkan masyarakat akan lingkungan yang sehat, rapi, dan bersih.

3. Untuk mengubah sampah menjadi sesuatu yang lebih berguna dalam masyarakat, misalnya untuk kerajinan dan pupuk yang memiliki nilai ekonomis.

\section{METODE PELAKSANAAN}

Sosialisasi ini dilaksanakan pada tanggal 19 Februari 2019 - 19 Maret 2019, dan tempat sosialisasi di Balai Desa Kalikatir, Kec Gondang, Kab. Mojokerto dengan pengambilan data berupa dokumentasi. Subjek dalam penelitian yang menghasilkan data deskriptif berupa kata- kata tertulis atau lisan dari orang-orang dan perilaku yang dapat diamati._Sosialisasi ini adalah ibu-ibu PKK desa Kalikatir yang terdiri dari 26 orang. Dimana pengambilan dokumentasi diambil selama pelaksanaan sosialisasi pemilahan sampah dan daur ulang di Balai Desa Kalikatir. Jenis penelitian yang dipakai di dalam penelitian ini adalah jenis penelitian kualitatif dengan pendekatan deskriptif.

\section{HASIL DAN PEMBAHASAN}

Dari 26 ibu-ibu PKK dari Desa Kalikatir didapatkan data sebagai berikut :

1. Kelompok A terdiri dari 6 ibu sudah memahami pentingnya pengelolaan sampah rumah tangga, dan sudah mulai memilih dan memilah sampah basah dan kering.

2. Kelompok B terdiri dari $10 \mathrm{ibu}$ sudah mengetahui pentingnya pengelolaan sampah rumah tangga, namun belum mulai melakukan aktivitas memilih memilah sampah rumah tangga.

3. Kelompok $\mathrm{C}$ terdiri dari $10 \mathrm{ibu}$ tidak peduli dengan sampah rumah tangga. 
Pengeloaan sampah rumah tangga hanya dibakar atau dipendam.

Dari ketiga kelompok ibu-ibu di Desa Kalikatir memiliki karakter yang berbeda. Dari kelompok A, ternyata sudah pernah mendapatkan pelatihan, dan menyadari pentingnya pilih, pilah sampah. Kelompok ini pun sudah mulai mendapatkan hasil dari budaya pilih pilah sampah, namun hasil sampahnya masih disetor ke lapak utama di Pasar Gondang. Kelompok B adalah kelompok yang sebenarnya berminat melakukan pilih pilah sampah, apalagi sudah mengetahui nilai ekonomis dari sampah, namun kelompok B ini adalah kelompok yang enggan menyetor sampah ke Pasar Gondang, yang jaraknya $5 \mathrm{Km}$ dari Desa Kalikatir. Kelompok C, adalah kelompok yang tidak peduli dengan pengelolaan sampah, meskipun sudah tahu. Namun apabila dilakukan wawancara lebih lanjut, kelompok $\mathrm{C}$ ini ternyata memiliki keinginan untuk menambah penghasilan dari tata kelola sampah.

Dari program bank sampah tim melakukan pengembangan bank sampah yang terdiri dari :

1. Pengembangan struktur bank sampah

2. Pengembangan daftar sampah dan nilai ekonomis yang dimiliki

3. Pengembangan buku tabungan sampah

4. Pengembangan penjadwalan pengambilan sampah

5. Pengembangan model penerimaan hasil bank sampah apakah berupa perorangan atau sampah komunal.

Pelaksanaan pengabdian hanya dilakukan satu bulan.Tingkat keberhasilan yang bisa diukur adalah ketersediaan peralatan persiapan Bank Sampah seperti tersedianya buku tabungan sampah dan sistem bank sampah. Namun untuk tingkat keberlanjutan pelaksanaan Bank Sampah
Kalikatir harus dilakukan upaya pendampingan berkelanjutan.

Sejauh ini pelaksanaan cukup berjalan, namun akan lebih baik jika ada penanganan yang lebih profesional. Jika memungkinkan bergabung dengan tiga desa lain disekitar kalikatir yaitu Desa Dilem dan Desa Begaganlimo.

\section{KESIMPULAN}

Hasil dari pengabdian ini adalah dari 26 orang ibu-ibu PKK hanya 6 orang yang sudah mulai melakukan proses pilih pilah sampah. Kondisi ini terjadi karena jarak antara Desa Kalikatir dengan Pasar Gondang adalah $5 \mathrm{Km}$. Ketersediaan Bank Sampah Desa Kalikatir tetap harus dilakukan upaya pendampingan. Jika memungkinkan ada upaya studi banding ibu-ibu penggiat Bank Sampah Desa ke lokasi Desa lain yang lebih maju, seperti Desa Menanggal Surabaya. Dampak dari pengabdian ini adalah mengawali budaya pilih pilah sampah dampaknya adalah warga Desa Kalikatir setidaknya sudah mampu memahami pentingnya.

\section{REFERENSI}

Anggraini, Ayu Dewanti, Dkk. Strategi Inovatif Pengelolahan Sampah Rumah Tangga Perkotaan. Jurnal Administrasi Publik (Jap), Vol. 3, No. 11.

Barat, T. et al. (2018) 'Pemberdayaan Masyarakat Melalui Pengelolaan Sampah Menjadi Nilai Ekonomis dan Pembentukan Bank Sampah', 1(2017), pp. 157-161.

Jastam, Saleh, 2015, Pemberdayaan

Masyarakat Melalui Pengelolaan

Sampah (Studi Kasus Di Bank Sampah

Pelita Harapan, Kelurahan

Ballaparang, Kecamatan Rappocini,

Makassar), Jurnal Higiene, Issn : 
2443-1141, Volume 1, No. 1,

Januari-April 2015, Hal 42-48

Maya, Haryono, Khoylisya, 2017,

Pemberdayaan Masyarakat Melalui

Pengelolaan Sampah Menjadi Nilai

Ekonomis Dan Pembentukan Bank

Sampah Di Kelurahan Tanjung

Barat, Proceding Of Community

Developemnet, Vol. 1: 157-161

Moleong, Lexy J. (2008) Metodologi

Penelitian Kualitatif. Bandung,

Remaja Rosda Karya.

Suryani, Elvira. 2016. Manajemen Pengelolahan Bank Sampah Di Kota

Bekasi. Jurnal Akp Vol. 6, No. 1 